\title{
Cause analysis and risk evaluation of the occurrence of Campylobacter spp. in the broiler production chain
}

\author{
A. Berkics ${ }^{1 *}$ (1), V. Varga ${ }^{1}$, Cs. Mohácsi-Farkas ${ }^{1}$ and Á.B. Jóźwiak ${ }^{2}$
}

${ }^{1}$ Department of Microbiology and Biotechnology, Faculty of Food Science, Szent István University, Somlói Street 14-16, 1118 Budapest, Hungary

${ }^{2}$ Digital Food Institute, University of Veterinary Medicine, István Street 2, 1078 Budapest, Hungary

\section{ORIGINAL RESEARCH PAPER}

\section{ABSTRACT}

Tendencies of foodborne outbreaks show that the number of illnesses caused by Campylobacter spp. has been increasing recently in the European Union and in Hungary as well. However, the epidemiological statuses of Member States are diverse. There are several aspects to be investigated by competent authorities before the introduction of interventions. Methods supporting food safety decision making range from quick and easy techniques to complex, resource consuming approaches. The aim of the present study was the implementation of an evaluation and ranking system for a risk and its causes occurring in the broiler production chain. Data and information available in scientific literature were converted to a structured easy-to-use evaluation that supports decision making and helps structured data processing.

\section{KEYWORDS}

campylobacter spp., food chain, intervention, cause analysis

\footnotetext{
*Corresponding author. Tel.: +36 706989107. E-mail: adrienn.berkics@gmail.com
} 


\section{INTRODUCTION}

Number of illnesses caused by Campylobacter spp. has been increasing recently in the European Union. According to the Zoonoses Report (EFSA-ECDC, 2019), campylobacteriosis was the most frequently reported zoonoses in the EU, and the number of cases is exceeding salmonellosis. Its symptoms can vary from mild gastroenteritis to long-term complications such as Guillain-Barré syndrome or reactive arthritis (EFSA, 2012). Member States attempt to manage the problem at different points of the food chain, in line with the structure of industry and the diverse prevalence. Multiple intervention points can be identified through the food chain, e.g. reduction of the levels of Campylobacter contamination in flocks and in fresh broiler meat (EFSA, 2020). Poultry flocks, especially broiler chickens, are considered to be the major cause of spreading Campylobacter spp. in the food chain (EFSA, 2011).

The amount of broiler chickens accounts for $81 \%$ of all poultry meat produced in the EU. Broilers are mainly raised in indoor intensive farming system, and the breeding is divided into steps performed in specialised establishments (Augère-Granier, 2019). Grandparent and parent flocks seem to be irrelevant as vertical transmission is insignificant (EFSA, 2020). Therefore, horizontal spread of Campylobacter in the Gallus gallus breeding and production chain was investigated.

There are several studies evaluating the risk associated with Campylobacter spp. in the food chain, differing in the covered processing stages (EFSA, 2020) and in the methodology applied. Assessment methods vary in their resource demand, e.g. time, data, knowledge, etc., which factors can be limiting in practice. Although, data and results of previous evaluations have enormous information value that has to be processed and integrated into decision making, especially when resources are restricted. Thus, the study aimed to implement a literature-based, structured evaluation approach supporting official decision making.

\section{MATERIALS AND METHODS}

\subsection{Mapping of broiler production process}

Narrative literature review has been carried out by means of scientific databases and the internet (Baker, 2016). Collection of information was limited to data on broiler chicken farming and processing. Actions significantly influencing the entry of Campylobacter spp. into the food chain were studied. The process describing the whole production chain was outlined, and stages proven to be irrelevant were excluded. In order to identify causes contributing to the spread of the pathogen, all remaining process steps were examined by the use of 3 questions, considering Campylobacter as the object of each event: 'What can happen?'; 'What was the cause?'; 'What interventions would mitigate the risk?'.

\subsection{Cause analysis and risk evaluation}

Following the mapping, the most important causes of hazard occurrence were collected and categorised by their logical and functional characteristics. Then accessible data, indicated in 
Tables 1, 3-4 (as shown in Results and discussion), were extracted from the literature and matched with causes identified. Since data on the target microorganism were not based on uniform mathematical models (Crotta et al., 2017), conversion and weighting were necessary. Where numerical data were available, values were matched with scores between 1 and 3 both for the conversion to a severity value (mild to severe), representing the extent of contamination, and an occurrence value (low to high), representing the probability of pathogen occurrence. Where numerical data were lacking, assumptions and scoring were made on the basis of information available. Risk value was obtained by the multiplication of the former two values resulting in a number between 1 and 9, forming 6 different categories: negligible, low, mild, moderate, major, and high.

During the evaluation hygiene and legal rules, good practices, subsequent disinfection possibilities, as well as the complexity of each step were investigated. Both scoring and risk value calculations were based on the data reviewed by the expert panel consisting of the Authors, including the consideration of the role of the process and the severity attributed to it. After the definition of risk values, corrective actions and possibilities for the elimination of arisen problems were examined.

\section{RESULTS AND DISCUSSION}

\subsection{Mapping of broiler production process}

In order to identify all possibly occurring causes, investigation covered all steps from broiler eggs to meat consumption and a process consisting of 21 stages have been set up (Fig. 1).

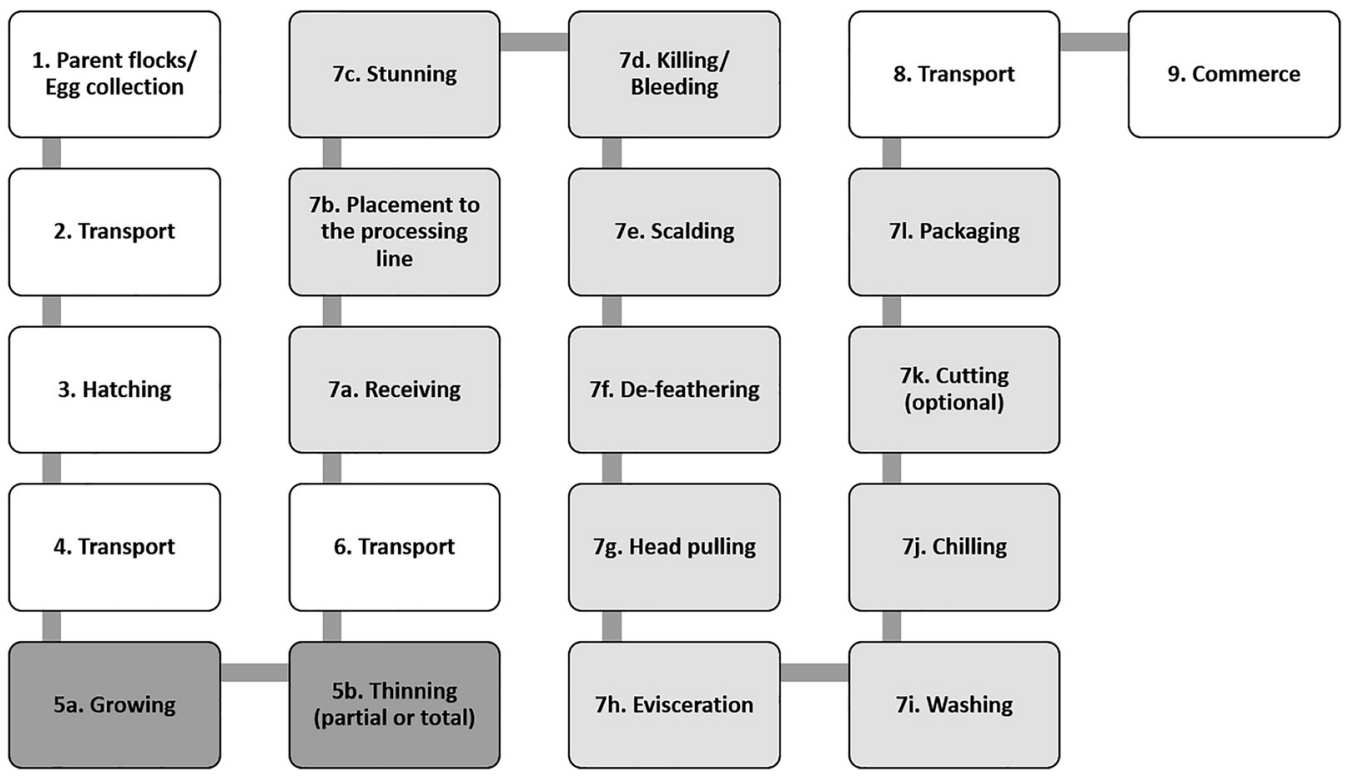

Fig. 1. Process of broiler meat production (gray colour indicates the most important stages) 
Grandparent flocks and consumption together with the delivery to households were excluded from the model, because the role of breeding is negligible in the spread of Campylobacter spp., and handling by consumers is out of the scope of competent authorities.

\subsection{Cause analysis and risk evaluation}

3.2.1. Parent flocks, transport, and hatching. At the level of primary production step by step investigation of hatching was unnecessary, however, eggs of different origin can contribute to contamination (Table 1). The only identified hazard occurring at the stage of parent flocks was contamination with Campylobacter. Mainly inappropriate training, lack of compliance with good manufacturing practices, and inappropriate management of technologies can be recognised as causes.

In terms of Campylobacter contamination, level of risk of the processes is less significant compared to the following production stages, however, correction and elimination of nonconformities as well as potential hazards are essential. A summary of the risk values is shown in Table 2. Occurrence of Campylobacter spp. in poultry flocks happens at the age of 2-4 weeks, namely in grow-out houses. Thus, process steps related to parent flocks, transport, and hatching are insignificant (Skarp et al., 2016). Causes of contamination at this stage can be managed by proper education, work organisation, and process control.

Table 1. Causes and corrective actions at the stage of parent flocks, transport, and hatching

\begin{tabular}{|c|c|c|c|}
\hline Food chain position & Cause & Corrective action & Reference \\
\hline \multirow[t]{5}{*}{$\begin{array}{l}\text { Parent flocks/Egg } \\
\text { collection }\end{array}$} & $\begin{array}{l}\text { Faecal contamination of egg } \\
\text { surface }\end{array}$ & $\begin{array}{l}\text { Technology optimisation, } \\
\text { appropriate padding }\end{array}$ & AA (2018) \\
\hline & Cracked shell & $\begin{array}{l}\text { Technology optimisation, } \\
\text { pliable surface }\end{array}$ & \\
\hline & Insufficient biosecurity & $\begin{array}{l}\text { Training, continuous } \\
\text { monitoring }\end{array}$ & \\
\hline & Bad timing of egg collection & $\begin{array}{l}\text { Data collection, work } \\
\text { organisation }\end{array}$ & \\
\hline & Inadequate egg disinfection & Technology optimisation & \\
\hline \multirow[t]{4}{*}{ Transport } & Improperly cleaned vehicle & $\begin{array}{l}\text { Continuous monitoring, } \\
\text { optimised cleaning, training }\end{array}$ & $\begin{array}{l}\text { Donofre et al } \\
\text { (2017) }\end{array}$ \\
\hline & $\begin{array}{l}\text { Inappropriate personal } \\
\text { hygiene }\end{array}$ & $\begin{array}{l}\text { Training, continuous } \\
\text { monitoring }\end{array}$ & \\
\hline & Knowledge scarcity & Training, knowledge survey & \\
\hline & Improper fixing & & \\
\hline \multirow[t]{3}{*}{ Hatching } & $\begin{array}{l}\text { Poor hygiene and personal } \\
\text { hygiene }\end{array}$ & $\begin{array}{l}\text { Training, continuous } \\
\text { monitoring }\end{array}$ & AA (2018) \\
\hline & Product line confluence & $\begin{array}{l}\text { Technology review and } \\
\text { optimisation, training }\end{array}$ & \\
\hline & Insufficient knowledge & Research, knowledge survey & \\
\hline \multirow[t]{3}{*}{ Transport } & $\begin{array}{l}\text { Poorly cleaned vehicle and } \\
\text { crates }\end{array}$ & $\begin{array}{l}\text { Continuous monitoring, } \\
\text { optimised cleaning, training }\end{array}$ & Shane $(2000)$ \\
\hline & $\begin{array}{l}\text { Inappropriate personal } \\
\text { hygiene }\end{array}$ & $\begin{array}{l}\text { Training, continuous } \\
\text { monitoring }\end{array}$ & \\
\hline & Knowledge scarcity & Training, knowledge survey & \\
\hline
\end{tabular}


Table 2. Evaluation of risks associated with relevant process steps

\begin{tabular}{|c|c|c|c|c|c|c|c|}
\hline Processing stage & Nr. & Process step & Severity & Occurrence & $\begin{array}{l}\text { Risk } \\
\text { value }\end{array}$ & $\begin{array}{l}\text { Risk } \\
\text { category }\end{array}$ & Description \\
\hline \multirow{4}{*}{$\begin{array}{l}\text { Parent flocks/ } \\
\text { Hatchery }\end{array}$} & 1 & Parent flocks/Egg collection & 1 & 1 & 1 & Negligible & \multirow{4}{*}{$\begin{array}{l}\text { Technologies listed here do not pose a } \\
\text { high risk to the whole production } \\
\text { chain, since the occurrence of } \\
\text { Campylobacter in chickens is } \\
\text { between the age of } 2 \text { and } 4 \text { weeks. } \\
\text { Problems arisen at this stage can be } \\
\text { managed by proper training, work } \\
\text { organisation, and process control. }\end{array}$} \\
\hline & 2 & Transport & 1 & 2 & 2 & Low & \\
\hline & 3 & Hatching & 2 & 2 & 4 & Moderate & \\
\hline & 4 & Transport & 1 & 2 & 2 & Low & \\
\hline \multirow[t]{3}{*}{ Grow-out } & $5 \mathrm{a}$ & Growing & 3 & 2 & 6 & Major & \multirow{3}{*}{$\begin{array}{l}\text { Prevention of Campylobacter } \\
\text { colonisation at flock level is the } \\
\text { most effective way to prevent its } \\
\text { latter appearance at the meat } \\
\text { production chain. Besides, } \\
\text { authorised decolonisation methods } \\
\text { are not available yet. }\end{array}$} \\
\hline & $5 b$ & Thinning & 3 & 3 & 9 & High & \\
\hline & 6 & Transport & 1 & 2 & 2 & Low & \\
\hline \multirow[t]{14}{*}{ Processing } & $7 \mathrm{a}$ & Receiving & 3 & 2 & 6 & Major & \multirow{14}{*}{$\begin{array}{l}\text { The most important step is the } \\
\text { separation of positive and negative } \\
\text { flocks before slaughter. It is } \\
\text { suggested that methods less likely } \\
\text { promoting the spread of } \\
\text { Campylobacter should be chosen. }\end{array}$} \\
\hline & $7 b$ & $\begin{array}{l}\text { Placement to the processing } \\
\text { line }\end{array}$ & 1 & 2 & 2 & Low & \\
\hline & $7 c$ & Stunning & 3 & 2 & 6 & Major & \\
\hline & $7 d$ & Killing/Bleeding & 1 & 2 & 2 & Low & \\
\hline & $7 \mathrm{e}$ & Scalding & 2 & 2 & 4 & Moderate & \\
\hline & $7 f$ & De-feathering & 2 & 2 & 4 & Moderate & \\
\hline & $7 \mathrm{~g}$ & Head pulling & 1 & 2 & 2 & Low & \\
\hline & $7 \mathrm{~h}$ & Evisceration & 2 & 2 & 4 & Moderate & \\
\hline & $7 \mathrm{i}$ & Washing & 3 & 2 & 6 & Major & \\
\hline & $7 \mathrm{j}$ & Chilling & 3 & 2 & 6 & Major & \\
\hline & $7 \mathrm{k}$ & Cutting & 1 & 2 & 2 & Low & \\
\hline & 71 & Packaging & 2 & 2 & 4 & Moderate & \\
\hline & 8 & Transport & 2 & 2 & 4 & Moderate & \\
\hline & 9 & Commerce & 2 & 2 & 4 & Moderate & \\
\hline
\end{tabular}


3.2.2. Grow-out farms. Before the arrival of day-old chicks to grow-out farms, cleaning, disinfection, and biosecurity measures must be applied. In order to avoid contamination, after chick placement enhanced biosecurity, safe water and feed supply, and controlled entry and exit must be ensured. When slaughter age is reached, partial or complete harvest can be carried out that means the removal of the whole flock ("all in-all out") or a part of it (thinning). Advantage of thinning is that the remaining flock can be grown further, however, it can contribute to bacterial infections. In parallel to catching and thinning, chickens are placed on transport vehicles (McDowell et al., 2008). Feed withdrawal is necessary, and it is possible 8-12 hours prior to slaughter (Northcutt, 2010).

Processes at grow-out farms are of key importance as the likelihood of Campylobacter infection is the highest at flock level (McDowell et al., 2008). Thus, controls at farm level are considered to be the most effective way for the reduction of human campylobacteriosis (EFSA, 2020). Implementation of most of the preventive actions belonging to this stage requires only increased attention and appropriate knowledge from the farm staff.

Causes identified at growing can be grouped into 6 categories that are most likely to be eliminated along with enhanced biosecurity measure (Table 3). Although, long-term effects and costs have to be preliminarily evaluated.

Risk evaluation has been carried out (Table 2), and the resulting higher values are due to the process complexity and the fact that infection of broiler flocks is most likely to occur during growing. Carcass disinfection is not allowed in poultry processing in the EU (EC, 2004), so the problem has to be addressed at a pre-slaughter stage: continuous sampling and testing should be applied in order to isolate Campylobacter positive flocks during both transport and slaughter, as well as reconsideration of the harvesting practice (thinning or all in-all out) is also necessary.

3.2.3. Processing. As for poultry processing, slaughter and processing take place within one plant, with a high degree of automation. Live animals are usually delivered in open crates, and after arrival, birds are taken to the processing line, where they are hung upside down on a conveyor belt, that is followed by stunning, neck cutting, and bleeding. As next, carcasses are scalded, plucked, decapitated, eviscerated, prechilled, and then packaged whole or in pieces (FAO/WHO, 2009).

Hazards occurring at processing are listed in Table 4. Highest risk can be associated with inadequate scheduling, as if a Campylobacter positive flock gets on the line at first, it will contaminate all equipment and previously uninfected carcasses. In general, training can make both hazard recognition and management more effective.

3.2.4. Evaluation of risks. Several processing steps received high risk values (Table 2), because these stages are involved in the spread of contamination. For this reason, continuous monitoring is of paramount importance, as is the increased training of the staff. Reevaluation of processes with a value of 6 or 9 is strongly recommended, and available legal procedures for minimising contamination should be examined also. Most of the hazards arisen can be avoided by process control, proper training and communication, appropriate information distribution, and compliance with relevant legislation and requirements. In many cases, impact of people who come into contact with product during processing is not given sufficient attention, however, staff should be dealt as part of the process. Many causes can be eliminated with the management of "customary law" by properly trained and motivated staff. 
Table 3. Causes and corrective actions at grow-out farms

\begin{tabular}{|c|c|c|c|c|}
\hline $\begin{array}{l}\text { Food chain } \\
\text { position }\end{array}$ & $\begin{array}{l}\text { Cause } \\
\text { category }\end{array}$ & Cause & Corrective action & Reference \\
\hline \multirow[t]{17}{*}{$\begin{array}{l}\text { Grow-out } \\
\text { farm }\end{array}$} & \multirow[t]{3}{*}{ Isolation } & $\begin{array}{l}\text { Other animals at farm/ } \\
\text { Rodent control }\end{array}$ & $\begin{array}{l}\text { Non - only if necessary } \\
\text { (safety distances)/ } \\
\text { Regular, planned and } \\
\text { compliant }\end{array}$ & \multirow[t]{3}{*}{$\begin{array}{l}\text { McDowell et al. } \\
\text { (2008), Borck Høg } \\
\text { et al. (2016) }\end{array}$} \\
\hline & & Number of barns & $\begin{array}{l}\text { Proper farm organisation, } \\
\text { safety distances }\end{array}$ & \\
\hline & & $\begin{array}{l}\text { Poultry and other } \\
\text { farms nearby }\end{array}$ & $\begin{array}{l}\text { Application of safety } \\
\text { distances } \\
(500-2000 \mathrm{~m})\end{array}$ & \\
\hline & \multirow[t]{3}{*}{ Hygiene } & $\begin{array}{l}\text { Use of detergents and } \\
\text { disinfectants }\end{array}$ & $\begin{array}{l}\text { Approved substances } \\
\text { only }\end{array}$ & \multirow[t]{3}{*}{ McDowell et al. (2008 } \\
\hline & & $\begin{array}{l}\text { Overall cleanness } \\
\text { (especially entrance) }\end{array}$ & $\begin{array}{l}\text { Enhanced, controlled } \\
\text { cleaning }\end{array}$ & \\
\hline & & $\begin{array}{l}\text { Application of } \\
\text { footbath, boot } \\
\text { change }\end{array}$ & $\begin{array}{l}\text { Compulsory - water and } \\
\text { boot changes several } \\
\text { times a day }\end{array}$ & \\
\hline & \multirow[t]{3}{*}{$\begin{array}{l}\text { Architectural } \\
\text { features }\end{array}$} & Material of curtains & $\begin{array}{l}\text { Not supporting microbial } \\
\text { growth, appropriate } \\
\text { barn design }\end{array}$ & \multirow[t]{5}{*}{ Torralbo et al. (2014) } \\
\hline & & $\begin{array}{l}\text { Hallway in front of the } \\
\text { barn }\end{array}$ & Compulsory & \\
\hline & & $\begin{array}{l}\text { Barn age and } \\
\text { condition }\end{array}$ & $\begin{array}{l}\text { New buildings, scheduled } \\
\text { maintenance }\end{array}$ & \\
\hline & \multirow[t]{2}{*}{ Feeding } & $\begin{array}{l}\text { Water treatment and } \\
\text { drinker type }\end{array}$ & $\begin{array}{l}\text { Approved substances } \\
\text { only and nipple } \\
\text { drinkers }\end{array}$ & \\
\hline & & Feed storage & $\begin{array}{l}\text { Clean silos (one silo per } \\
\text { barn), safe feed }\end{array}$ & \\
\hline & \multirow[t]{4}{*}{ Technology } & $\begin{array}{l}\text { Flock age/Removal of } \\
\text { dead animals }\end{array}$ & $\begin{array}{l}\text { Slaughter as soon as } \\
\text { possible/As required }\end{array}$ & \multirow{4}{*}{$\begin{array}{l}\text { McDowell et al. } \\
\text { (2008), Borck Høg } \\
\text { et al. (2016) }\end{array}$} \\
\hline & & $\begin{array}{l}\text { Farm and } \\
\text { slaughterhouse } \\
\text { distance }\end{array}$ & $\begin{array}{l}\text { Proper timing of feed } \\
\text { withdrawal }\end{array}$ & \\
\hline & & Thinning & $\begin{array}{l}\text { All in/all out, technology } \\
\text { design }\end{array}$ & \\
\hline & & Downtime & $\begin{array}{l}\text { Optimisation } \\
\text { (epidemiology versus } \\
\text { finance) }\end{array}$ & \\
\hline & Other factors & $\begin{array}{l}\text { Seasons/Owner's level } \\
\text { of education }\end{array}$ & $\begin{array}{l}\text { Not influenceable/ } \\
\text { Regulated by law }\end{array}$ & $\begin{array}{l}\text { Ansari-Lari et al. } \\
\text { (2011) }\end{array}$ \\
\hline & & Early use of antibiotics & $\begin{array}{l}\text { Suggested with attention } \\
\text { to antimicrobial } \\
\text { resistance }\end{array}$ & \\
\hline \multirow[t]{2}{*}{ Transport } & \multirow[t]{2}{*}{-} & $\begin{array}{l}\text { Improperly cleaned } \\
\text { vehicles and crates }\end{array}$ & $\begin{array}{l}\text { Continuous monitoring, } \\
\text { optimised cleaning, } \\
\text { training }\end{array}$ & \multirow[t]{2}{*}{ Bull et al. (2006) } \\
\hline & & $\begin{array}{l}\text { Knowledge scarcity, } \\
\text { poor personal } \\
\text { hygiene }\end{array}$ & $\begin{array}{l}\text { Training, knowledge } \\
\text { survey, continuous } \\
\text { monitoring }\end{array}$ & \\
\hline
\end{tabular}


Table 4. Causes and corrective actions at processing

\begin{tabular}{|c|c|c|c|}
\hline $\begin{array}{l}\text { Food chain } \\
\text { position }\end{array}$ & Cause & Corrective action & Reference \\
\hline Receiving & $\begin{array}{l}\text { Lack of separation of } \\
\text { positive and negative } \\
\text { flocks }\end{array}$ & $\begin{array}{l}\text { In situ colonisation test, } \\
\text { training, production plan } \\
\text { reevaluation, } \\
\text { communication with } \\
\text { suppliers }\end{array}$ & Miwa et al. (2003) \\
\hline $\begin{array}{l}\text { Placement to } \\
\text { processing line }\end{array}$ & $\begin{array}{l}\text { Contaminated transport } \\
\text { equipment, type of } \\
\text { equipment } \\
\text { Hygiene shortcomings }\end{array}$ & $\begin{array}{l}\text { Imposing penalty on } \\
\text { suppliers, easy to clean } \\
\text { crates } \\
\text { Strict hygiene requirements, } \\
\text { training }\end{array}$ & Seliwiorstow et al. (2016) \\
\hline Stunning & $\begin{array}{l}\text { Faecal material released } \\
\text { on carcasses hung by } \\
\text { legs during electrical } \\
\text { stunning }\end{array}$ & $\begin{array}{l}\text { Hanging by neck or gas } \\
\text { stunning }\end{array}$ & \\
\hline Killing/Bleeding & $\begin{array}{l}\text { Non-compliance with } \\
\text { hygiene rules }\end{array}$ & $\begin{array}{l}\text { Strict hygiene requirements, } \\
\text { training }\end{array}$ & \\
\hline \multirow[t]{2}{*}{ Scalding } & $\begin{array}{l}\text { Low decrease in cell count } \\
\text { due to low scalding } \\
\text { water temperatures }\end{array}$ & $\begin{array}{l}\text { Process optimisation, } \\
\text { proper water temperature } \\
\text { (safety versus quality) }\end{array}$ & FAO/WHO (2009) \\
\hline & $\begin{array}{l}\text { Contamination due to } \\
\text { conventional scalding }\end{array}$ & $\begin{array}{l}\text { Counterflow scalding, } \\
\text { technology optimisation }\end{array}$ & \\
\hline \multirow[t]{2}{*}{ De-feathering } & $\begin{array}{l}\text { Cross contamination of } \\
\text { flocks due to bad } \\
\text { scheduling }\end{array}$ & $\begin{array}{l}\text { Reevaluation of the } \\
\text { production plan }\end{array}$ & $\begin{array}{l}\text { FAO/WHO (2009), } \\
\text { Seliwiorstow et al. } \\
\text { (2016) }\end{array}$ \\
\hline & $\begin{array}{l}\text { Faecal contamination and } \\
\text { intestine damage due to } \\
\text { intense mechanical } \\
\text { plucking }\end{array}$ & Technology optimisation & \\
\hline \multirow[t]{2}{*}{ Head pulling } & Hygiene shortcomings & $\begin{array}{l}\text { Strict hygiene requirements, } \\
\text { training }\end{array}$ & FAO/WHO (2009) \\
\hline & $\begin{array}{l}\text { Carcass contamination by } \\
\text { crop content due to } \\
\text { upward head removal }\end{array}$ & $\begin{array}{l}\text { Technology optimisation } \\
\text { (downward head } \\
\text { removal) }\end{array}$ & \\
\hline Evisceration & $\begin{array}{l}\text { Intestine and carcass } \\
\text { damage due to } \\
\text { improper settings, too } \\
\text { long feed withdrawal } \\
\text { and the lack of weight } \\
\text { uniformity }\end{array}$ & $\begin{array}{l}\text { Technology optimisation, } \\
\text { proper grow-out plan and } \\
\text { scheduling, compromise } \\
\text { with suppliers, carcass } \\
\text { classification and } \\
\text { equipment adjustment }\end{array}$ & Berrang et al. (2000) \\
\hline Washing & $\begin{array}{l}\text { Low decrease in cell count } \\
\text { due to bad practices }\end{array}$ & Training & Meredith et al. (2013) \\
\hline \multirow[t]{2}{*}{ Chilling } & $\begin{array}{l}\text { Contamination by cooling } \\
\text { water }\end{array}$ & Technology optimisation & Sukte et al. (2017) \\
\hline & Inappropriate chilling & $\begin{array}{l}\text { Proper chilling design, } \\
\text { application of approved } \\
\text { additives }\end{array}$ & \\
\hline $\begin{array}{l}\text { Cutting (optional)/ } \\
\text { Packaging }\end{array}$ & Hygiene shortcomings & $\begin{array}{l}\text { Strict hygiene requirements, } \\
\text { training }\end{array}$ & FAO/WHO (2009) \\
\hline $\begin{array}{l}\text { Transport/ } \\
\text { Commerce }\end{array}$ & $\begin{array}{l}\text { Failure of cold chain and } \\
\text { hygiene shortcomings }\end{array}$ & $\begin{array}{l}\text { Strict hygiene and chilling } \\
\text { requirements }\end{array}$ & EC (2005) \\
\hline
\end{tabular}




\section{CONCLUSIONS}

The applied data organisation and weighting method is suitable for supporting decision making, since it was able to identify in total 6 steps representing "major" or "high" risk, and 7 stages that received "medium" risk score. In line with food chain safety approach, hazards should be targeted as early as possible in the chain. In case of Campylobacter spp. exact point of appearance is still debated, moreover, specific control measures are still not available. Because of this lack of a 'single best' solution, the additive effect of different interventions along the production chain should be utilised. This is also underpinned by our findings that values of different severity are located at different points of the food chain, which indicates that Campylobacter control measures must be applied throughout the food chain and continuous monitoring is essential. For further refinement of the method, sensitivity analysis and validation by an extended expert group can be conducted.

\section{ACKNOWLEDGEMENT}

The study has been supported by the Doctoral School of Food Sciences of Szent István University, EFOP-3.6.3-VEKOP-16-2017-00005.

\section{REFERENCES}

AA (2018). Arbor acres - parent stock handbook.

Ansari-Lari, M., Hosseinzadeh, S., Shekarforoush, S.S., Abdollahi, M., and Berizi, E. (2011). Prevalence and risk factors associated with Campylobacter infections in broiler flocks in Shiraz, southern Iran. International Journal of Food Microbiology, 144: 475-479.

Augère-Granier, M.-L. (2019). The EU poultry meat and egg sector - main features, challenges and prospects. Brussels.

Baker, J.D. (2016). The purpose, process and methods of writing a literature review. AORN Journal, 103(3): 265-269.

Berrang, M.E., Dickens, J.A., and Musgrove, M.T. (2000). Effects of hot water application after defeathering on the levels of Campylobacter, coliform bacteria, and Escherichia coli on broiler carcasses. Poultry Science, 79(11): 1689-1693.

Borck Høg, B., Sommer, H.M., Larsen, L.S., Sørensen, A.I., David, B., Hofshagen, M., and Rosenquist, H. (2016). Farm specific risk factors for Campylobacter colonisation in Danish and Norwegian broilers. Preventive Veterinary Medicine, 130: 137-145.

Bull, S.A., Allen, V.M., Domingue, G., Jørgensen, F., Frost, J.A., Ure, R., Whyte, R., Tinker, D., Corry, J., Gillard-King, J., and Humphrey, T.J. (2006). Sources of Campylobacter spp. colonizing housed broiler flocks during rearing. Applied and Environmental Microbiology, 72(1): 645-652.

Crotta, M., Georgiev, M., and Guitian, J. (2017). Quantitative risk assessment of Campylobacter in broiler chickens - assessing interventions to reduce the level of contamination at the end of the rearing period. Food Control, 75: 29-39. 
Donofre, A.C., Silva, I.J.O., Nazazerno, A.C., and Ferreira, I.E.d.P. (2017). Mechanical vibrations in the transport of hatching eggs and the losses caused in the hatch and quality of broiler chicks. Journal of Agricultural Engineering, 48(1): 36-41.

EC (2004). Regulation 852/2004/EC of the European Parliament and of the Council on the hygiene of foodstuffs.

EC (2005). Regulation 2073/2005 of the European Commission on microbiological criteria for foodstuffs.

EFSA (2011). Scientific opinion on Campylobacter in broiler meat production: control options and performance objectives and/or targets at different stages of the food chain. The EFSA Journal, 9(4): 2105.

EFSA (2012). Scientific Opinion on the public health hazards to be covered by inspection of meat (poultry). The EFSA Journal, 10(6): 2741.

EFSA (2020). Update and review of control options for Campylobacter in broilers at primary production. The EFSA Journal, 18(4): 6090.

EFSA-ECDC (2019). The European union one health 2018 zoonoses Report. The EFSA Journal, 17(12), 5926. FAO/WHO (2009). Risk assessment of Campylobacter spp. In broiler chickens: Technical report. Geneva.

McDowell, S.W., Menzies, F.D., McBride, S.H., Oza, A.N., McKenna, J.P., Gordon, A.W., and Neill, S.D. (2008). Campylobacter spp. in conventional broiler flocks in Northern Ireland: epidemiology and risk factors. Preventive Veterinary Medicine, 84: 261-276.

Meredith, H., Walsh, D., McDowell, D.A., and Bolton, D.J. (2013). An investigation of the immediate and storage effects of chemical treatments on Campylobacter and sensory characteristics of poultry meat. International Journal of Food Microbiology, 166: 309-315.

Miwa, N., Takegahara, Y., Terai, K., Kato, H., and Takeuchi, T. (2003). Campylobacter jejuni contamination on broiler carcasses of $C$. jejuni-negative flocks during processing in a Japanese slaughterhouse. International Journal of Food Microbiology, 84: 105-109.

Northcutt, J.K. (2010). Factors influencing optimal feed withdrawal duration. The University of Georgia. http://athenaeum.libs.uga.edu/bitstream/handle/10724/12477/B1187.pdf.

Seliwiorstow, T., Baré, J., Berkvens, D., Van Damme, I., Uyttendaele, M., and De Zutter, L. (2016). Identification of risk factors for Campylobacter contamination levels on broiler carcasses during the slaughter process. International Journal of Food Microbiology, 226: 26-32.

Shane, S.M. (2000). Campylobacter infection of commercial poultry. Revue scientifique et technique (International Office of Epizootics), 19(2): 376-395.

Skarp, C.P.A., Hänninen, M.L., and Rautelin, H.I.K. (2016). Campylobacteriosis: the role of poultry meat. Clinical Microbiology and Infection, 22(2): 103-109.

Sukte, N., Tuitemwong, P., Tuitemwong, K., Poonlapdecha, W., and Erickson, L.E. (2017). Inactivation of Campylobacter during immersion chilling of chicken carcasses. Journal of Food Engineering, 202: 25-33.

Torralbo, A., Borge, C., Allepuz, A., García-Bocanegra, I., Sheppard, S.K., Perea, A., and Carbonero, A. (2014). Prevalence and risk factors of Campylobacter infection in broiler flocks from southern Spain. Preventive Veterinary Medicine, 114: 106-113.

Open Access. This is an open-access article distributed under the terms of the Creative Commons Attribution 4.0 International License (https://creativecommons.org/licenses/by/4.0/), which permits unrestricted use, distribution, and reproduction in any medium, provided the original author and source are credited, a link to the CC License is provided, and changes - if any - are indicated. (SID_1) 